\title{
ON SCRIPTAE: CORRELATING SPELLING AND SCRIPT IN LATE MIDDLE ENGLISH
}

\author{
Jeremy Smith \\ University of Glasgow
}

\begin{abstract}
In 1963, Michael Samuels identified a sequence of late Middle English spelling-patterns that he termed "types of incipient standard". Other "types" have since been identified, e.g. in copies of John Gower's Confessio Amantis and Nicholas Love's Mirror of the Life of Christ. This article argues that manuscripts containing such texts, which were also transmitted in distinctive forms of handwriting and in similar codicological contexts, were products of identifiable communities of practice, and that the correlation of spelling and handwriting such manuscripts manifest represented "expressive" usages characteristic of particular kinds of discourse. Such scriptae, as they might be called, seem to "function as markers of difference and belonging, and be involved in the creation of identities at different levels of social organisation" (Sebba 36). This paper attempts to bring paleography and book history into the realm of linguistic enquiry, as part of a reimagined philology.
\end{abstract}

KeYwords: Writing-systems, spelling, palaeography, communities of practice, scriptae, reimagined philology.

\author{
SCRIPTAE, CORRELACIÓN ENTRE ORTOGRAFÍA \\ Y CALIGRAFÍA EN EL INGLÉS MEDIO TARDÍO
}

\section{RESUMEN}

En 1963, Michael Samuels identificó una serie de modelos ortográficos en el inglés medio tardío a los que denominó «tipos de estándar incipiente». Desde entonces se han señalado otros "tipos", como por ejemplo en las copias del Confessio Amantis de John Gower y el Mirror of the Life of Christ de Nicholas Love. Este artículo defiende que los manuscritos soporte de tales textos, aquellos que también fueron transmitidos con caligrafías distintivas y en contextos codicológicos similares, fueron el producto de comunidades de práctica identificables. La correlación entre ortografía y caligrafía que se manifiesta en estos manuscritos, representa usos «expresivos» propios de tipos específicos de discurso. Estos que podemos designar como scriptae parecen funcionar, en palabras de Sebba (36) como "markers of difference and belonging, and be involved in the creation of identities at different levels of social organisation». Este trabajo intenta trasladar la paleografía y la historia del libro al ámbito de la investigación lingüística como parte de una reconceptualización de la filología. PAlabras Clave: Sistemas de escritura, ortografía, paleografía, scriptae, reconceptualización de la filología.

DOI: https://doi.org/10.25145/j.recaesin.2020.80.02

Revista Canaria de Estudios Ingleses, 80; April 2020, pp. 13-27; ISSN: e-2530-8335 


\section{ON WRITING SYSTEMS}

In comparison with the study of sounds, the study of writing -from a linguistic point of view- remains, with some honourable exceptions, surprisingly under-researched. It is for that reason, no doubt, that even the term for the study is uncertain: graphonomy, graphology, graphiology, and grammatology have all been used at various times and various places, and with various theoretical connotations. And much of the most insightful work in this area, most notably for Anglicists interested in early English studies that by the late Angus McIntosh, dates from the 1950s through the 1970s. Only in recent years has there been a change, as evidenced by the appearance of dedicated journals such as Writing Systems Research, first published in 2009.

Why this comparative neglect? One reason may be that writing has generally been seen by linguists as essentially secondary to speech, and thus intrinsically 'less interesting. Thus the traditional terms to describe writing systems, viz. logographic and phonographic, refer to the writing-speech relationship. To sum up briefly: in a phonographic language there is a mapping (however conventional) between grapheme and phoneme (or cluster of phonemes), while in a logographic language, where there is a mapping between a conventional symbol and a word or morpheme. The relationship between these different systems is of course clinal, and many languages which are essentially phonographic often frequently deploy logographs, e.g. symbols such as ' 8 ' or ' $\&$ ' in English texts, corresponding to phonographic 'eight' and 'and' in English but 'huit' and 'et' in French. The discourse community of educated writers and readers of standard written English have in such cases mutually agreed that the signifiers 'eight' and ' 8 ' map onto a signified numerical concept (see further Smith's "Issues of Linguistic Categorization" and references there cited). But in both systems the issue is to do with the mapping between written and spoken signifier.

The same relationship existed in antiquity, where, according to the doctrine of littera developed by authorities such as Donatus and Priscianus, a written figura ('figure') mapped onto a spoken potestas ('power'), with a shared nomen ('name') (see Benskin's "The Letter $\langle\mathrm{p}\rangle$ " and references there cited). This usage underpins the traditional method for teaching initial literacy in western European languages, according to which, for instance, the figura $\langle\mathrm{c}>$, with the nomen /si:/, expresses or "says" the potestas $/ \mathrm{k} /$. In this case too, of course, the mapping between writing and speech is explicit.

Yet a little thought indicates that written language has a quite distinct function from speech. The latter, ever since it first emerged in human society until the invention of speech-recording at the end of the nineteenth century, has been necessarily evanescent. Writing, however, emerged for the specific purpose of communication across time and space -originally it seems for the recording of business transactions as societies became more complex. This functional distinction has significant implications for the formal characteristics of writing-systems.

Another issue is to do with the distinction between the figura, which is commonly referred to by modern linguists as a grapheme, or as the grapheme's realisation, or allograph. Here there is an overlap between linguistic study and 
disciplines generally seen as distinct, such as paleography (the study of older forms of handwriting) and typography (the study of printed letter-forms). These latter disciplines have themselves developed their own distinctive terminology for allographic usages. Typographers thus classify typefaces (or fonts) as Arial, Baskerville, Calibri, Caslon, Garamond, Gill Sans, Times New Roman and so on. Many of these fonts, as their names suggest, had distinctive cultural associations; thus, for instance, roman fonts were first developed by the great Venetian printers in the fifteenth century as a humanist attempt to recuperate in print the appearance of high-status handwriting and inscriptions from antiquity. In Britain the roman font became usual for editions of Latin texts in the sixteenth century, competing with antiquarian "Gothic" blackletter, in Britain sometimes referred to as pica English, which was used for the printing of texts inherited from the medieval vernacular tradition. Typographical choice was therefore culturally meaningful.

Comparable behaviours, with (mutatis mutandis) similar cultural connotations, can be discerned in the history of handwriting. Almost all present-day English educated cursive ("joined up") handwriting is modelled ultimately on the clerks' script of the eighteenth and nineteenth centuries: the famous round hand celebrated in (e.g.) Gilbert and Sullivan's HMS Pinafore. A script, or "ideal" usage, is and was realised in the handwriting (i.e. the hands) of individuals, and thus the manifestations of modern handwriting are very varied. However, all hands aim, more or less successfully in terms of communicative effectiveness, at a particular scriptmodel (for the distinction, see Parkes, passim).

Before the emergence of the round-hand script, other scripts were commonly deployed. The most notable in English texts were: italic, used in the sixteenth and seventeenth centuries as a humanistic script; secretary, the common cursive script from the fifteenth through the seventeenth centuries, commonly deployed in documents; anglicana, the cursive book-script used in the production of literary manuscripts from the fourteenth century onwards; and textura, a non-cursive script used for the reproduction of high-status texts where the speed possible with cursive scripts such as anglicana or secretary was not a requirement.

It is interesting to note that the script/hand distinction, whereby paleographers and analysers of modern handwriting distinguish between a script (the model in a scribe's mind's eye) and a hand, the actual and distinctive realisation of the script by an individual scribe, clearly mirrors the emicletic categorisation so characteristic of linguistic enquiry. However, it is notable that -with comparatively few exceptionsscholars have not correlated disciplines such as paleography and typography with broader trends in linguistics. In this paper, an attempt is made to bring them into closer articulation, as part of a reimagined philology. The approach taken here relates to an issue with which Jose Gómez Soliño has been closely associated: the emerging standardisation of written English at the end of the medieval period. 


\section{TYPES OF 'INCIPIENT STANDARD'}

Notoriously, Middle English was the 'age of written dialects', where an item like Through is recorded, in the Linguistic Atlas of Late Mediaeval English (= LALME), in 500 different spellings, ranging from broadly recognisable (from a present-day perspective) thurgh and thorow through poro, pruz to such exotic-seeming forms as 3 urx, dorz etc. From a modern perspective such variety seems chaotic, but in medieval terms the variety of usages is comprehensible; if you and I have agreed, within our discourse community, that a form such as <zurx> is our spelling for the item THROUGH then there is no difficulty, and only becomes problematic if we wish to use the spelling in communicating with other discourse communities with different practices. In Middle English conditions there was a widespread (and prestigious) alternative to using written English to communicate over time and space: use Latin. Only towards the end of the medieval period did written English start to take over some national rather than local or restricted functions, and that change underpins the rise of more commonplace spellings and the disappearance of forms with more restricted currency.

For many years, the accepted account of spelling-standardisation was that first developed by the late Michael Samuels in 1963, in his article "Some applications of Middle English dialectology". The date is significant: in 1963, many of the major developments in the historical study of language, notably the rise of historical sociolinguistics as a distinctive approach to the subject, had not yet happened (indeed, Samuels in later work may be taken as a prime mover in that latter development, notably in his classic monograph Linguistic Evolution). So, it is perhaps not surprising that some of his formulations made in the 1963 article have suffered from subsequent over-interpretation.

Perhaps the most influential of these formulations was Samuels's identification of what he referred to as "Types" of "incipient standard". Drawing on his extensive experience in the analysis of the manuscript evidence for the Middle English Dialect Project, which later resulted in the appearance of the first version of LALME some twenty years later, Samuels identified four Types that could be distinguished by the appearance of groups of particular English spellings in clusters of manuscript witnesses. Type I, according to Samuels, appeared in the latter half of the fourteenth century and persisted in use until the middle of the fifteenth, while Types II through IV represented a chronological sequence over the same period, reflecting what he interpreted as patterns of immigration into the capital.

In Samuels's typology, Type I - which he referred to as "Central Midlands Standard"- was a usage which as its name suggests was based on that commonly found in Middle English dialects of the central midlands. Type I texts characteristically use a mixture of forms common in the Central Midland counties in Middle English times, e.g. sich 'such', mych 'much', ony 'any', silf'self', stide 'stead', zouun 'given', siz 'saw'. Types II, III and IV, the remaining 'incipient standards' he identified, represented varieties of English found in discrete clusters of texts whose language was localised or localisable in the London area. Characteristic of Type II is the present participle inflexion in -ande, and the lexeme perk 'dark', both found 
otherwise in Norfolk and Suffolk; such forms led Samuels to correlate the rise of Type II with a perceived pattern of immigration from East Anglia, encouraged by the social disruption associated with the Black Death. Other characteristic Type II forms include werld 'world', pat ilch(e), ilch(e) 'that very', noiper, noper 'neither', pei(3) 'though', pai, hij 'they'. Frequently attested Type III forms - many of them the same as in Present-Day written English-include world, thilke, that ilk(e) 'that very', neither, though, they, yaf 'gave', nat 'not', swich (e) 'such', bot 'but', hir(e) 'their', thise 'these'. Characteristic Type IV forms include gaf'gave', not 'not', but, such(e), theyre etc. 'their', thes (e) 'these', thorough/porowe 'through', shulde 'should'.

Samuels's four "Types" have received a lot of commentary and criticism since they were first described in 1963, some of it misconceived. It is important to realise that the Types represent focused -not fixed-usage within the cline "that is the total range of [Middle English] dialectal variation" (Sandved, 39); they are not in any way "standards" comparable with Present-Day "educated" written English, i.e. a usage that has undergone all the stages of standardisation usually identified, viz. selection, elaboration, codification and acceptance (for which see classically Haugen).

Since Samuels's discussion, further research -not least the rise of historical sociolinguistics as a distinctive and relevant discipline- has taken matters forward without, I would argue, occluding the basic typology. Type I (so-called "Central Midlands Standard"), which Samuels associated with inter alia Wycliffite texts, is now better seen as a broad lingua franca adopted widely to promulgate university learning into the vernacular. The remaining usages, viz. Types II through IV, which Samuels saw as varieties characteristic of or originating in London, -as has already been flagged- are seen now as reflecting waves of immigration into the capital during the fourteenth and early fifteenth centuries. ${ }^{1}$ Type II forms are found in such manuscripts as Cambridge, Magdalene College, MS Pepys 2498 and Edinburgh, National Library of Scotland, Advocates' MS 19.2.1 (the Auchinleck Manuscript), from the middle to the end of the fourteenth century. Type III forms appear in key literary manuscripts of Chaucer and Langland dating from around 1400, e.g. the well-known Ellesmere manuscript of the Canterbury Tales (San Marino, Huntington Library, MS EL 26 C.9), and also in some London documents. Type IV forms are commonly found in certain government documents after about 1430; for that reason, Samuels in 1963 perhaps rather unfortunately labelled this Type as "Chancery Standard" (a formulation based on German Kanzlerdeutsch). This terminology has been especially controversial because of attempts made, notably by John Fisher and his associates, to link the usage with a supposed Lancastrian "language policy". ${ }^{2}$

1 This correlation between the "Types" and demographic change has been recently challenged, notably in forthcoming work by Laura Wright, presented in an important keynote paper at the International Conference on Middle English in Florence, 2019. I do not propose to address that issue here; as I hope will become apparent, I am taking a different approach to the Types.

${ }^{2}$ For an extended outline of the standard account of the four Types, see Smith's $A n$ Historical Study of English 68-73; the sequencing of the Types is perhaps not as clear-cut as a casual reading of "Some Applications of Middle English dialectology" by Samuels might suggest. It is worth 


\section{ON SCRIPTS}

Another area of research that has developed hugely since 1963 has been in the area of paleography and codicology, now generally subsumed in the larger discipline of book history. Especially noteworthy for the purposes of this paper has been the work undertaken by scholars such as Ian Doyle and Malcolm Parkes, and subsequently by Linne Mooney and her associates Simon Horobin and Estelle Stubbs, on the identification of scribes active in more than one manuscript (see especially Mooney and Stubbs, and Horobin).

Seminal in this context was an important article published by Doyle and Parkes in "The Production of Copies of the Canterbury Tales and the Confessio Amantis in the Early Fifteenth Century". In this article the authors identified a cluster of scribes active in the large-scale production of key literary texts -not just these works but also including writings by other major fourteenth-century authors such William Langland and John Trevisa-in the London area. The article abounded with insights, not least the conclusion that two scribes were each responsible for copying two of the four most important early manuscripts of the Canterbury Tales, and that these scribes had also contributed to the copying of a multi-scribe manuscript of the Confessio Amantis. Subsequently, Linne Mooney and her team have identified a host of manuscripts that can be assigned to particular scribes, and they have even gone on -although the ascription has been subsequently challenged- to assign names to these copyists, most famously Adam Pinkhurst, "Chaucer's own scribe" (see famously Mooney's article "Chaucer's Scribe").

Mooney and Stubbs associated many of these scribes with the activities of London's Guildhall, but even if this association is not accepted it is clear that these men, many of whom were clearly engaged on a collaborative venture, viz. the production of major literary manuscripts, formed what in many disciplines has become known as a "community of practice". The notion, first identified in Lave and Wenger-Trayner, began in anthropological and educational studies, but rapidly

noting that, given the dynamic growth of London in the late Middle Ages, the city would have been a linguistic melting pot. See also Smith's "John Gower and London English" and "Chaucer and London English", and references there cited. For some further thoughts on Type II, see also Hanna. For an authoritative discussion of "Chancery Standard", including a critique of especially Fisher's views on its status, see Benskin's “'Chancery Standard" and references there cited. Many insightful comments on the complexities of standardisation of spelling in the late medieval period were pursued further by Samuels in a later article of 1981, "Spelling and dialect", which explicitly drew on the major research undertaken by Jose Gómez Soliño, especially in his important doctoral thesis which he pursued in part, early in his career, while a native language assistant at Glasgow University. It is possible that scholars -including, I should confess, myself in earlier publications- have focused overly, and arguably anachronistically, on "standard language" during the late medieval period, and should instead -as I will argue shortly- see these Types as distinct kinds of linguistic practice rooted in societies where vernaculars had roles rather different from their present-day functions. Arguably the only real standard written language in England, in the late medieval period, was Latin. 
spread into other fields, including linguistics. Penelope Eckert and Sally McConnellGinet have defined the notion as follows:

A community of practice is an aggregate of people who come together in mutual engagement in an endeavor. Ways of doing things, ways of talking, beliefs, power relations -in short practices- emerge in the course of this mutual endeavor. As a social construct, a community of practice is different from the traditional community, primarily because it is defined simultaneously by its membership and by the practice in which that membership engages (464).

Communities of practice are to be distinguished from, though overlap with, two other notions in widespread use in pragmatic studies: social networks and discourse communities. In social network research, which is widely practised in several disciplines (e.g. history, sociology and anthropology, politics and economics), links between groups and individuals may be mapped in terms of close or weak social ties. Perhaps especially relevant for the current paper, however, is the notion of discourse communities, i.e. communicative networks that engage with a common world-view and express their ideologies -however conflicting- in mutually comprehensible ways. However, communities of practice differ from discourse communities in that while the latter share a common language they do not share a mutual endeavour. ${ }^{3}$

Whether or not the precise identification of individuals by Mooney and her team is accepted -and as Simon Horobin has argued in a recent conference presentation ${ }^{4}$, such identifications are essentially a matter of greater-or-less plausibility, as is often the case in historical research-it is fairly clear that the scribes engaged in the production of literary manuscripts in London in the first decades of the fifteenth century characteristically deployed a distinctive form of handwriting: anglicana formata. To illustrate: some 26 manuscripts of the Confessio Amantis have been dated to the first quarter of the fifteenth century. Of these manuscripts, no fewer than 19 are either written wholly or largely in anglicana formata. A similar picture can be given for the Canterbury Tales, where all six of the principal early witnesses for the text were copied in anglicana formata: the aforementioned Ellesmere manuscript; Aberystwyth, National Library of Wales, MS Peniarth 392D (the Hengwrt manuscript); London, British Library, MS Harley 7334; Oxford, Corpus Christi College, MS 198; London, British Library, MS Lansdowne 851; and Petworth House, Kent, MS 7. The appearance of anglicana formata in an earlier London document, the Petition of the Folk of Mercerye from 1387 (see Chambers and Daunt), shows that the usage was already commonly deployed in the administrative circles in which Chaucer moved, as did scribes such as Adam Pinkhurst and those like him.

${ }^{3}$ On discourse communities, see Swales. For communities of practice as distinct from discourse communities, see the collection of papers edited by Joanna Kopaczyk and Andreas Jucker.

${ }^{4}$ At a symposium held in York in 2019 to mark Linne Mooney's retirement. I understand that the paper is shortly to be published. 
The deployment of this calligraphic form of cursive handwriting -a new development at the period, replacing earlier less elaborate scripts- is presumably a response to the expectations of the target discourse community for attractive copies of what was becoming a "canonical" set of literary texts associated with an anglophone court culture. Such copies were produced by communities of scribal practice of the kind Mooney and her associates have identified, even if one quibbles -as some haveabout the precise identification of the scribes in question. Whether or not these scribes worked together as part of a distinctive "Guildhall group" (Mooney and Stubbs) $)^{5}$, it seems likely that such scribes nevertheless formed a distinct community of practice, writing for a particular set of discourse communities who would have become increasingly accustomed -and might have come to expect- to encounter such written-language features.

Book historians - most notably Ralph Hanna- have also in recent years identified earlier comparable communities of practice in the London area. Cambridge, Magdalene College, MS Pepys 2498 is an impressively large book that was put together in London in the second half of the fourteenth century. Of the manuscript's nine medieval items, several are translated from Anglo-Norman: a translation from Robert de Greetham's Miroir; an exposition on the ten commandments preceded by an account of the pains of hell and the joys of heaven; an annotated Apocalypse; a prose Complaint of Our Lady; and a translation of the Gospel of Nicodemus. A Latin Psalter with an interlinear Middle English gloss also appears. Other texts are English in origin: a Gospel Harmony, unique to the manuscript, introducing the translation of the Miroir; a clutch of short prayers at the volume's end; and, placed between the glossed Psalter and the Complaint, a copy of the early Middle English Ancrene Riwle in a modified form: Pis good book Recluse. The Pepys scribe also copied at least two other, more modest manuscripts: London, British Library, MS Harley 874, and Oxford, Bodleian Library, Laud Misc. MS 622. The main text in Harley 874 is the annotated Apocalypse found in Pepys 2498, although set out more simply; Harley's decoration is restricted to the unshowy deployment of simple red initials.

Hanna has compared Pepys 2498 with another contemporary London book: the well-known Auchinleck manuscript of Middle English romances, now Edinburgh, National Library of Scotland, Advocates' MS 19.2.1. Unlike Auchinleck, Pepys 2498 contains only devotional writings in prose. However, like Auchinleck, the Pepys manuscript draws in many instances from materials originating in the West Midlands. All four manuscripts are copied in an earlier version of anglicana, with very comparable deployment of rubrication, used especially for shading initial letters in verse-lines.

Typologically in terms of contents Laud 622 is positioned between Pepys and Auchinleck, bringing together the former's religious concerns with the romance contents of the latter. Laud's main text is the romance of Kyng Alisaunder (folios 27v-

\footnotetext{
5 See Warner, and references there cited, for a different view. Simon Horobin's response in this lively controversy has already been referred to; see footnote 4 above.
} 
64r), followed by a note of remarkable things and places to be seen by pilgrims to the Holy Land (folios 64r-64v). Other texts include The Siege of Jerusalem (possibly the most widely-circulated Middle English alliterative poem apart from Piers Plowman); The Vision of St Alexius; Adam Davy's Five Dreams about Edward II; an incomplete Temporale; Fifteen Tokens before the Day of Judgement; and Lines on the Birth of Christ. It may be noted that Kyng Alisaunder also appears in the Auchinleck Manuscript, and indeed in appearance and layout Laud 622 is very similar to Auchinleck. It seems therefore very plausible that all four manuscripts are products of the same London book-trade, and quite possibly the same "community of practice", designed for the use of a distinct "in-and-out-of-court" discourse community, possibly for the court of Edward III or for the family reading of a socially-aspirant merchant (Doyle). As Hanna argues, both Pepys 2498 and Auchinleck

were produced for similar London audiences. In both [...] the same activities of literary appropriation occur, for both are imitative products which present English texts derived from aristocratic Anglo-Norman environments (Hanna 154).

Much recent research has focused, as these examples demonstrate, on the London book-trade: an explicable focus, given the astonishing growth in the city's size and importance during the later medieval period. However, it is important to realise that comparable behaviours can be distinguished outside the metropolis from the late fourteenth century onwards. Perhaps the best known such pattern is that associated with Lollardy, the hugely-influential "premature Reformation" initiated by the Oxford theologian John Wycliffe at the end of the fourteenth century. As Mary Dove and others have demonstrated, Lollardy was a team-effort, and although -because it was swiftly condemned- those involved in such enterprises as the production of the "Wycliffite Bible" translation tended to keep their involvement anonymous, it is, as Dove conclusively argues, clear that

the production of the first English Bible was conceived as a group endeavour. The translators did far more than turn the Latin Bible into English. Their hugely ambitious project involved editorial, hermeneutic and linguistic biblical scholarship. Aware that one of the most telling arguments against biblical translation was the danger of translating from a corrupt text of the Latin Bible, the translators wanted to give their English readers a Bible they could rely upon as an apt and accurate rendering of a carefully edited original (Dove 79).

Although there are -perhaps surprisingly, given what has just been cited-a wide variety of formats for Wycliffite bibles and associated texts, there is a tendency for them to be presented in a particular script: non-cursive textura. Textura emerged as a high-status script in the middle ages, deployed where speed was not a primary requirement but where the scribe wished to flag the special dignity of the work in question: choosing textura, in other words, was a foregrounded vector of meaning for the discourse community that encountered it.

The "meaningfulness" of textura may be illustrated easily from some copies of the Wycliffite Bible. Oxford, Bodleian Library, MS Bodley 277 is an enormous 
display pandect of this text, copied in textura between c.1415-30 and owned -we might think rather surprisingly -by a Carthusian monastery. It contains -along with a comprehensive collection of navigational aids, including little tabs of parchment attached to the edges of leaves to mark books of scripture- cues such as in refectorio ('in the refectory') "sometimes followed with the number of folios to be read" (Wakelin 90). ${ }^{6}$

Bodley 277 is therefore a "display" pandect, and it is perhaps unsurprising that it is presented in a high-status script such as textura. However, it is worth noting that textura could also appear in humbler copies of the same text. For instance, Glasgow, University Library, MS Hunter 176 (T.8.8) is an early fifteenth-century copy of the Wycliffite Bible measuring $15.9 \times 10.8 \mathrm{~cm}$ : a small object, with - by comparison with Bodley 277 - modest decoration. Yet it too is copied in a version of the textura script, a sign of the esteem in which the text was held. And another manuscript of the Wycliffite translation of the Pauline epistles, Edinburgh, National Library of Scotland, MS 6127, is even smaller $-12 \times 8 \mathrm{~cm}-$ but is similarly presented in a calligraphic textura script accompanied by a complex system of rubrication, including internal glossing of words apparently deemed obscure by means of a binomial underlined in red, e.g. we moun conforte hem $p^{t}$ ben in al pressure or ouerleijnge by pe exortacon or monestinge. Many other copies of the Wycliffite Bible, e.g. the important "earlier version" in Oxford, Bodleian Library, MS Bodley 959, used as the basis for the modern edition for the work (Lindberg), were similarly presented.

\section{ON SCRIPTAE}

There would seem therefore to distinctive clusters of texts associated with particular script-types during the late medieval period; and knowledgeable readers will have observed that these clusters are linked not only by the deployment of particular scripts but by particular spellings. In his seminal article of 1963, Samuels flagged the sources for his first three Types as follows:

Type I (inter alia):

"A majority of the manuscripts of Wyclif's sermons and tracts [...] Practically all copies of the later version of the Lollard Bible, and most copies of the earlier version."

Type II:

"The full list comprises:

(i) Auchinleck MS hands 1 and 3.

(ii) The Early English Prose Psalter in BL Add 17376.

(iii) MS BL Harley 5085.

${ }^{6}$ Wakelin supplies a fine illustration of the manuscript (88-9). 
(iv) Three manuscripts in the hand of a single scribe: Magdalene College Cambridge Pepys 2498, Bodley Laud Misc. 622, and BL Harley 874.

(v) St John's College Cambridge MS 256.

(vi) Glasgow Hunterian MS 250.'

Type III "is represented chiefly by":

"(i) A number of the documents printed in Chambers and Daunt, London English 1384-1425, ${ }^{7}$ and in Furnivall, Early English Wills. ${ }^{8}$

(ii) The language of Chaucer, as vouched for by a consensus of the best MSS, corroborated by the evidence of (i).

(iii) The text of Piers Plowman in Trinity College Cambridge B.15.17.

(iv) The language of Hoccleve, as established by a consensus of the MSS."

It would seem that, with regard to witnesses, there is a rough correlation between the three Types of (to use Samuels's term) "incipient standard" and the deployment of particular scripts: textura for Type I, anglicana for Type II, and anglicana formata for Type III (which appears in the sources distinguished as (i)-(iii) above). Although more archival research across all these witnesses is certainly required to make the arguments conclusive, and there are undoubtedly exceptions -Hoccleve's own autograph manuscripts survive ${ }^{9}$, and are both written in a variety of secretary script- there is a clear tendency here that is worth further investigation. It is certain that questions of communities of practice -and of the expectations of discourse communities- will be central in any such programme of research.

However, it should also be noted that such tendencies cut across other patterns and correlations characteristic of vernacular usages during the period, where the correlations are not so clear-cut. Here the Gower tradition -which as we have seen was in the first decades of the fifteenth century characteristically presented in anglicana formata- is rather distinct. Many of the linguistic features found in the earliest manuscripts of the Confessio will be familiar to any student of Chaucer who will have almost certainly first encountered that poet's writings as transmitted through the spellings and grammar of the Ellesmere manuscript. Grammatical features common to both Ellesmere and the most authoritative early manuscripts of "the Gower tradition", e.g. Oxford, Bodleian Library, MS Fairfax 3, and San Marino, Huntington Library, MS EL 26 A.17, include, for instance, the inflected form of the vocative adjective in Mi goode fader, compared with the uninflected strong form in som good ansuere; the inflected plural hise $e^{I 0}$; the present plural verb in -en, e.g. helpen; and the pronoun hem 'them' (alongside pei 'they' elsewhere).

7 i.e. Chambers and Daunt 1931.

8 i.e. Furnivall 1882.

9 San Marino, Huntington Library, MSS HM 744 and HM 111, and Durham, University Library, MS Cosin V.iii.9.

${ }^{10}$ In the form hise, the inflexion -e, being an analogical linguistic innovation, is not counted towards the iambic measure of the line. 
Spellings in Fairfax 3 that align with Type III include bot 'but', schold(e), whan 'when', wol 'will' etc.

Other forms in Fairfax 3 are somewhat distinct from those in Ellesmere, but not uncommon in London texts of the period, as witnessed by (for instance) the documents collected by Chambers and Daunt. Some forms such as noght 'not' (cf. prototypical Ellesmere nat, though noght is a minor variant in that manuscript), such (e) (cf. Ellesmere swiche), pese (cf. Ellesmere pise) are not especially regionally distinctive. The spelling ferst 'first', though traditionally a south-eastern usage, is fairly common in many texts that can be localised to London at the time.

However, other forms are more uncommon within the Middle English dialect continuum, and certainly atypical of late fourteenth-century London usage. For instance the present participle inflexion in -ende, in wakende, and the syncopated third person singular verb in makp, though not unknown in earlier London texts, would undoubtedly have been considered archaic by the Ellesmere scribe -they were certainly recessive in Middle English dialects- while the spelling oghne 'own' (adjective) would have seemed decidedly odd; the online LALME has sporadic records of oghne and similar forms (e.g. oghene) from the North Midlands, but there is a much more focused cluster in Kent. These non-London usages, when supplemented by forms from elsewhere in Fairfax 3, such as seluer 'silver', soster 'sister', perwhiles pat 'while', bopen 'both', zoue 'given', or ... or 'either ... or' and medial <- $h$-> in hyhe 'high', sihe 'saw' etc, enabled Michael Samuels and myself many years ago to identify the language of Fairfax 3 -in all scribal stints- as a mixture of Kentish and Suffolk usage (see Samuels and Smith). And since this distinctive usage was also found in other copies of the Confessio with a distinct genetic ancestry reaching back to the archetypal ancestor of the text, such as the Stafford manuscript, it seemed to Samuels and myself a reasonable assumption to consider this archetypal language to be that of John Gower; that Gower was associated with land-ownership in Kent and Suffolk would seem to offer some support to -albeit of course not absolute proof of- this conclusion.

Whether or not our localisation of the archetypal language of the Gower tradition with Gower's own usage is still accepted, it is nevertheless an intriguing fact that a number of these linguistic features persisted in the Gower tradition through and beyond the fifteenth century. Of the 49 extant manuscripts of the Confessio, for instance, no fewer than 30 retain forms of 'own' with medial - gh-, either as oghne, oughne or in a slightly modified form, e.g. ogne. Variants of sihe 'saw' (cf. Ellesmere saugh) are even better attested in the Confessio, appearing in 43 witnesses, including the printed editions by Caxton (1483) and Berthelette $(1532,1554)$.

It is clear, therefore, that a precise correlation of script and Samuels's Types is not to be had. Such fuzzy matching is however to be expected at a time when, although the dignity of English as a written language is beginning to emerge there are no clear models as to which form of English is to be the model. As is increasingly being noted, linguistic standardisation in the written mode is a complex business. The traditional view was that standardisation emerged as a result of the increasing "top-down" prestige of a particular model usage, viz. that found in late medieval/early modern London, and such prestige must be part of the story. But more important, 
it is now understood, were also "bottom-up" pressures to do with communicative function: as literacy in English became more widespread, with readers likely to encounter a wider range of new texts, so what Samuels back in 1963 termed -to modern eyes rather inappropriately- "grosser provincialisms" became more communicatively inconvenient, and were replaced by forms with wider currency at the time when the text was being reproduced (see Smith's "Standard language in Early Middle English?", 136 and references there cited). Such linguistic choices of less dialectally distinctive forms represent decisions made on pragmatic grounds, aimed at improving the legibility of the text for the intended discourse communities for whom the texts were being produced.

Nevertheless, it seems clear from the arguments presented in this paper that there are some patterns, however fuzzy: model usages associated with particular clusters of texts, both in terms of scripts and spellings. Scripts and spellings are features of what has been called "expressive form" (Bell 632) relating to dynamic, shifting socio-cultural processes, imperatives and functions as those texts are transmitted across time and space. Such "written-language" features can be said, in Mark Sebba's helpful formulation, to "function as markers of difference and belonging, and be involved in the creation of identities at different levels of social organisation' (36). They form what have recently come to be called scriptae, usages characteristic of particular discourses and transmitted through the activities of particular communities of practice. And the argument of this paper has been that the discussion of such scriptae, as part of a recuperated or reimagined philology, requires disciplines such as linguistics and paleography, hitherto seen as distinct, to be brought into closer articulation. ${ }^{11}$

Reviews sent to author: 11 January 2020 Revised paper accepted for publication: 28 January 2020

11 The identification of the Types with particular genres/text-types was to my knowledge first suggested in a conference paper by the late Matti Rissanen, but I owe the recuperation and repurposing of the term scripta-derived from the practice of French philologists- to Wendy Scase. For the term, see e.g. von Wartburg, and more recently Cerquiglini. Bringing together the broad set of philological disciplines, perhaps within such powerful overarching frames as historical pragmatics, seems to be an important step forward for research in this area. For a developed discussion of such matters, see Smith's forthcoming Transforming Early English. 


\section{WORKS CITED}

Bell, Maureen. 2002. "Mise-en-page, Illustration, Expressive Form: Introduction." The Cambridge History of the Book in Britain IV: 1557-1695. Ed. John Barnard, Donald F. McKenzie and Maureen Bell, Cambridge: Cambridge University Press, 2002. 632-635.

Benskin, Michael. “'Chancery Standard.” New Perspectives on English Historical Linguistics II: Lexis and Transmission. Eds. Christian Kay, Carole Hough and Irene Wotherspoon. Amsterdam: Benjamins, 2004. 1-40.

Benskin, Michael. "The Letter $<\mathrm{p}>$ and $<\mathrm{y}>$ in Later Middle English, and Some Related Matters." Journal of the Society of Archivists 7 (1982): 13-30

Benskin, Michael, Margaret Laing, Vasilis Karaiskos \& Keith Williamson. An Electronic Version of A Linguistic Atlas of Late Mediaeval English. Edinburgh. 2013. 14 Nov. 2019. http:// www.lel.ed.ac.uk/ihd/elalme/elalme.html.

Benskin, Michael \& Michael L. Samuels, eds. So Meny People Longages and Tonges: Philological Essays in Scots and Mediaeval English presented to Angus McIntosh. Edinburgh: Benskin and Samuels, 1981.

Cerquiglini, Bernard. La Naissance du Français. Paris: Presses Universitaires de France, 1991.

Chambers, Raymond W. \& Marjorie Daunt, eds. A Book of London English 1384-1425. Oxford: Clarendon Press, 1931.

Dove, Mary. The First English Bible. Cambridge: Cambridge University Press, 2007.

Doyle, A. Ian. "English Books in and out of Court from Edward III to Henry VII." English Court Culture in the Later Middle Ages. Ed. V.J. Scattergood and J. W. Sherborne. London: Duckworth, 1983.163-182.

Doyle, A. Ian \& Malcolm B. Parkes. "The Production of Copies of the Canterbury Tales and the Confessio Amantis in the Early Fifteenth Century." Medieval Scribes, Manuscripts and Libraries: Essays Presented to N.R.Ker. Ed. Malcolm B. Parkes and Andrew G. Watson. London: Scolar, 1978. 163-210.

Eckert, Penelope, \& Sally McConneld-Ginet. "Think Practically and Look Locally: Language and Gender as Community-based Practice”. Annual Review of Anthropology 21 (1992) 461-490.

Furnivall, Frederick J., ed. The Fifty Earliest English Wills. London: EETS, 1882.

Gómez Soliño, José. Variación y Estandarización en el Inglés Moderno Temprano 1470-1540, diss. $\mathrm{PhD}$ (Oviedo), 1984.

Hanna, Ralph. London Literature, 1300-1380. Cambridge: Cambridge UP, 2005.

Horobin, Simon. "Adam Pinkhurst, Geoffrey Chaucer and the Hengwrt Manuscript of the Canterbury Tales." The Chaucer Review 44 (2010): 351-367.

Haugen, Einar. "Dialect, Language, Nation”. American Anthropologist, New Series 68:4 (1966): 922-935.

Kopaczyк, Joanna \& Andreas H. Jucker, eds. Communities of Practice in the History of English. Amsterdam: John Benjamins, 2013.

Lave, Jean, and Etienne Wenger-Trayner. Situated Learning. Cambridge: Cambridge UP, 1991.

Lindberg, Conrad, ed. MS. Bodley 959: Genesis-Baruch 3.20 in the Earlier Version of the Wycliffite Bible. Stockholm: Almqvist and Wiksell, 1959-73. 
McIntosh, Angus. "Scribal Profiles from Middle English Texts." Neuphilologische Mitteilungen 76 (1975): 218-35.

McIntosh, Angus. "The Analysis of Written Middle English." Transactions of the Philological Society (1956): 26-55.

McIntosh, Angus. “Towards an Inventory of Middle English Scribes.” Neuphilologische Mitteilungen 75 (1974): 602-24.

Mooney, Linne. “Chaucer's Scribe." Speculum 81 (2006): 97-138.

Mooney, Linne, \& Estelle Stubis. Scribes and the City: London Guildhall Clerks and the Dissemination of Middle English Literature 1375-1425. York: York Medieval Press, 2013.

Parkes, Malcolm. English Cursive Book Hands 1250-1500. Oxford: Clarendon Press, 1969.

Samuels, Michael L. "Some Applications of Middle English Dialectology." English Studies 44 (1963): 81-94.

SAmuels, Michael L. "Spelling and Dialect in the Late and Post-Middle English Periods." In Benskin and Samuels (eds.), 1981. 43-54.

Samuels, Michael L. Linguistic Evolution. Cambridge: Cambridge University Press, 1972.

Samuels, Michael L. \& Jeremy J. Sмiтн. "The Language of Gower." Neuphilologische Mitteilungen 82 (1981): 295-304.

SAndved, Arthur. "Prolegomena to a Renewed Study of the Rise of Standard English.” In Benskin and Samuels (eds.), 1981. 31-42.

Sebba, Mark. “Sociolinguistic Approaches to Writing Systems Research.” Writing Systems Research I, (2009): 35-49.

Sмiтh, Jeremy J. "Chaucer and London English", Geoffrey Chaucer in Context. Ed. Ian Johnson. Cambridge: Cambridge University Press, 2019. 35-42.

Sмith, Jeremy J. "Issues of Linguistic Categorisation in the Evolution of Written Middle English". Medieval Texts in Context. Ed. Denis Renevey \& Graham D. Caie. New York: Routledge, 2008. 211-224.

Sмiтh, Jeremy J. “John Gower and London English." A Companion to Gower. Ed. Sian Echard. Cambridge: Brewer, 2004. 61-72.

Sмiтh, Jeremy J. "Standard Language in Early Middle English?” Placing Middle English in Context. Ed. Irma Taavitsainen, Terttu Nevalainen, Päivi Pahta and Matti Rissanen Berlin: Mouton de Gruyter, 2000. 125-139.

Sмiтн, Jeremy J. An Historical Study of English. London: Routledge. 1996.

Sмiтн, Jeremy J. Transforming Early English. Cambridge: Cambridge UP, 2020 (forthcoming).

Swales, John. Genre analysis: English in Academic and Research Settings. Cambridge: Cambridge UP, 1990.

Wakelin, Daniel. Designing English. Oxford: Bodleian Library. 2018.

Warner, Lawrence. Chaucer's Scribes: London Textual Production, 1384-1432 Cambridge: Cambridge UP, 2018.

von Wartburg, Walther. Evolution et Structure de la Langue Française. Berne: Francke, 1946. 
